\title{
Yaratıcı Drama Temelli Sınav Kaygısı İle Başetme Çalışmasının Özel/Üstün Yetenekli Öğrencilerin Sınav Kaygısına Etkisi
}

\section{The Effect of Coping with Test Anxiety Study Based Creative Drama on Gifted Students' Test Anxiety}

\author{
Prof. Dr. Zeynep KARATAŞ ${ }^{1}$, Doç. Dr. Özlem TAGAY ${ }^{2}$
}

\begin{abstract}
Özet
$\mathrm{Bu}$ çalı̧̧mada özel/üstün yetenekli lise öğrencilerinin sınav kaygısı puanları üzerinde yaratıcı drama temelli sınav kaygısı ile başetme çalışmasının etkililiğinin incelenmesi amaçlanmıştır. Araştırmanın deney ve kontrol grubunu 2016-2017 eğitim öğretim y1lında Bilim ve Sanat Merkezine devam eden 28 özel/üstün yetenekli lise öğrencisi oluşturmuştur. Bu öğrencilerden 14'ü deney (5 erkek, 9 kız) grubunda 14'ü kontrol grubunda (4 erkek, $10 \mathrm{kız}$ ) yer almaktadır. Çalışmada deney grubuna katılanlar gönüllülük esasına göre belirlenmiştir. Deney grubu ile 60 dakika süren 6 oturumluk yaratıcı drama temelli sınav kaygısı ile başetme çalışması yapılmıştır. Çalışmada 20 maddeden oluşan Sınav Kaygısı Ölçeği kullanılmıştır. Araştırmada ön-test, son-test, kontrol gruplu yarı deneysel desen kullanılmıştır. Yaratıcı drama temelli sınav kaygısı ile başetme eğitimi çalışmasına katılan deney grubu katılımcılarının ve bu uygulamaya katılmayan kontrol grubu katılımciların son test puanları karşılaştırılmış ve sınav kaygısı son test puanlarında deney grubu lehine anlamlı farklılıklar bulunmuştur.
\end{abstract}

Anahtar Kelimeler: Üstün yetenekli, sınav, sınav kaygısı, yaratıcı drama

Makale Türü: Araştırma makalesi

\begin{abstract}
In this study, it was aimed to investigate the effectiveness of the coping with test anxiety study based creative drama on scores of gifted high school students. Experimental and control group of the research comprised of 28 gifted high school students who attended Science and Art Center in the 2016-2017 academic year. Of these students, 14 were in the experimental group (5 males, 9 females) and 10 in the control group (4 males, 10 females). Participants in the study group were determined on a voluntary basis. With the experiment group, 60-minute 6-sessions test anxiety study based on creative drama was conducted. The Study Anxiety Scale consisting of 20 items was used in the study. Pre-test, post-test, control group semi-experimental design was used in the research. Participants of the experimental group participating in the test anxiety training study based on creative drama and participants in the control group who did not participate in this study were compared and there were significant differences in the test anxiety post-test scores in favor of the experimental group.
\end{abstract}

Keywords: Gifted, anxiety, test anxiety, creative drama

Paper Type: Research paper

\footnotetext{
${ }^{1}$ Burdur Mehmet Akif Ersoy Üniversitesi Eğitim Fakültesi, zeynepkaratas1972@hotmail.com, Orcid ID: http://orcid.org/ 00000002-4532-6827

2 Burdur Mehmet Akif Ersoy Üniversitesi Eğitim Fakültesi, ozlemtagay@gmail.com, Orcid ID: http://orcid.org/0000-00029821-5960
} 


\section{Giriş}

Son yıllarda eğitimde bireysel farklılıklar daha çok dikkat çekmektedir. $\mathrm{Bu}$ farkl11ıklar duygusal, sosyal, gelişimsel alanda olabileceği gibi bilişsel alanda, zekâ ve yetenekler konusunda da olabilmektedir. Farklılıklar arttıkça öğrencilerin ihtiyaçları, ilgileri ve gereksinimleri de değişmektedir. Bu farklılıklara cevap verebilmek için öğretmenlerin öğrencileri çok iyi tanıması ve özelliklerini bilmesi oldukça önemlidir. Yapılan bazı çalışmalar özellikle özel/üstün yetenekli bireylerin özelliklerinin öğretmenler tarafından çok iyi tanınmadığını göstermektedir (Manning, 2006; Westberg ve Daoust, 2003). Özel/üstün yetenekli bireyleri tanımlamada kullanılan özel yetenekli kavramı zaman zaman üstün entelektüel özellik zaman zaman da üstün akademik beceri olarak ifade edilmiştir (Manning, 2006). Bazı araştırmacılar (Clark, 2002) ise çeşitli beyin fonksiyonlarının üstün olarak gelişmesi sonucu oluşan biyolojik bir durum olarak ortaya çıktığını ve bunun sonucunda da bilişsel alanda, akademik alanda, yaratıc1lıkta, liderlikte ve sanatta farklılıkla kendini gösterdiğini belirtmektedir. Alan yazındaki ifadeler doğrultusunda MEB (2016) Bilim ve Sanat Merkezleri yönergesinde özel yetenekli bireyi yaşıtlarına göre daha hızlı öğrenen; yaratıcılık, sanat, liderliğe ilişkin kapasitede önde olan, özel akademik yeteneğe sahip, soyut fikirleri anlayabilen, ilgi alanlarında bağımsız hareket etmeyi seven ve yüksek düzeyde performans gösteren birey olarak tanımlamaktadır.

Toplumdaki normal gelişim gösteren bireylerde olduğu gibi özel yetenekli bireyleri de gelişimsel, sosyal, bilişsel ve kişilik özellikleri açısından tanımak gerekir. Bireyin kişilik özelliklerine de yansıyan kaygı son yıllarda insanın kişilik özellikleri ile ilişkili olarak en çok araştırılan kavramlardan birisi olmuştur. Kaygının karmaşık yapısı ve pek çok sebebin etken olması nedeniyle pek çok araştırmaya konu olmuştur. Bu çalışmaların bir kısmında kaygıyı etkileyen psikolojik faktörler bir kısmında çevresel faktörler bir kısmında kişisel faktörler bazılarında ise nörolojik faktörler ele alınmaktadır. Bu faktörlerin hangisi ele alınırsa alınsın kayg1 evrensel bir durumdur ve zaman zaman olumlu etkiler yarattığı gibi yoğun yaşandığında da olumsuz bir takım sorunları da beraberinde getirir. Kaygı ile ilgili dikkat çeken ilk çalışmaları yapan ve daha sonra da bu çalışmalarını yoğunlaştıran Spielberger (1972), kaygıyı otonom sinir sistemi ile bağlantılı olarak fizyolojik reaksiyon eşliğinde bir durumun ya da olayın hoş olmayan bir duygu olarak algilanması olarak ifade edilen durumluk kaygı ve bireysel olarak çeşitli durumlarda tehdit ve tehlike algılama eğilimi şeklinde yaşanan sürekli kaygı olarak iki şekilde ele almıştır.

Sınav bilgi ve becerilerin ölçülmesi ya da değerlendirilmesi anlamına gelen bir durum olarak adlandırılmaktadır. Sınav kaygısı da bu durum ya da olay öncesinde ya da geçmişte yaşanmış herhangi bir durumdan kaynaklı olarak daha sonra ortaya çıkabildiği için durumluk kaygının bir formu olarak değerlendirilmektedir. Çeşitli araştırmalarda sınav kaygısının öğrenciler arasında yaşanan yaygın bir durum olduğu ve öğrencilerin yaklaşık \%30'unun sınav kaygisı yaşadığı belirtilmektedir (Nasser, 1994, Shaked, 1996, Akt. Lufi, Okasha ve Cohen, 2004). Sınav kaygısı yaşayan kişilerin kendileri ile ilgili olumsuz benlik algıları ve beklentileri olduğu, bu olumsuz benlik algisı ve beklentiler doğrultusunda kendini beğenmeme alışkanlıkları ve tutumları olduğu, kaygı uyandıran durumlara karşı korkularının olduğu, aşırı fizyolojik aktivitelerinin olduğu ve sınav öncesi ya da sınav esnasında bu aşırı uyarılmanın kişinin durum değerlendirmesini etkilediği belirtilmektedir (Spielberger, 1972). 
Alan yazında sınav kaygısının, bilişsel, duyuşsal, fizyolojik olarak karmaşık çok boyutlu bir yapısı olduğu ve değerlendirme durumlarında davranışsal tepkiler olarak tanımlandığı (Hong, 1998) görülürken başka bir çalışmada sınav kaygısının endişe, gerginlik, bedensel belirtiler ve sınavla ilgisiz düşünceler olarak dört yapıda incelendiği görülmektedir (Sarason, 1984). Ayrıca sınav kaygısı performansın ölçüldüğü ve değerlendirildiği durumlarda gösterilen negatif duygusal ve bilişsel yanıt olarak da değerlendirilmektedir (Vogelaar, Bakker, Elliott ve Resing, 2016). Farklı bir çalışmada sınav kaygısı endişe ve duygusallık olarak ele alınmış (Liebert ve Morris, 1967) endişenin sınava bağlı bilişsel sıkıntı olduğu, duygusallığın ise sınav esnasındaki fiziksel belirtileri (sinirlilik, korku, fiziksel rahatsızlık vs.) ifade ettiği vurgulanmıştır.

Sınav kaygısının sadece normal bireylerde gözlenebilecek bir durum olduğu düşünülmektedir. Bu yüzden çoğu insan, üstün yeteneklilerin sınavlardan normal gelişim gösteren akranlarına göre daha yüksek puan alacaklarını düşünür, üstün yetenekli çocukların bir kısmı gerçekten de sınavlardan yüksek puanlar alabilirler. Ancak bir kısmı da standart testlerde kendisinden beklenilen başarıyı gösteremezler. Yapılan araştırmalarda ortaya çıkan motivasyon eksikliği, mükemmeliyetçilik, aşırı düşünme, kendine aşırı güven, aşırı sınav kaygısı, dağınıklık veya üstün yetenekliliğe eşlik eden farklı sorunlar bu farklılığa sebep olarak gösterilebilir (Özbay, 2013).

Alan yazında normal gelişim gösteren öğrencilerin sınav kaygıları ile ilgili yapılmış çok sayıda çalışma olduğu görülürken (Örn: Alyaprak, 2006; Akın ve Demirci, 2012; Başarır, 1990; Barrows, Dunn, Lloyd, 2013; Benson ve El-Zahhar, 1994; Çabulcuoğlu ve Gündüz, 2013; Demirci ve Erden, 2016; Dobson, 2012; Gençdoğan, 2006; Hong, 1998; Kaçan Softa, Ulaş Karaahmetoğlu ve Çabuk, 2015; Liebert ve Morris, 1967; Lufi, Okasha ve Cohen, 2004; Öner, 1990; Rana ve Mahmood, 2010; Sarason, 1984; Spielberger, 1972; Ünalan, Çifçili, Dinç, Akman ve Topçuoğlu, 2017; Yıldız, 2007) özel/üstün yetenekli öğrencilerin sınav kaygısı ile ilgili gerçekleştirilen sınırlı sayıda çalışma olduğu görülmektedir (Beer, 1991; Goetz, Preckel, Zeidner ve Schleyer, 2008; Kirişçi, 2013; Konyalıoğlu, 2013; Mısırlı Taşdemir, 2003; Moore, 2006; Özbay, 2002; Ols, 2014; Uyanık, 2007; Wholuba, 2014; Vogelaar, Bakker, Elliott ve Resing, 2017; Zeidner ve Schleyer, 1999a; Zeidner ve Schleyer, 1999b). Sınırlı sayıda olan bu çalışmalar incelendiğinde ise çok azının (Konyalığlu, 2013; Pols 2014; Vogelaar, Bakker, Elliott ve Resing, 2017) özel/üstün yetenekli öğrencilerde sınav kaygısını azaltmaya yönelik deneysel çalışma olduğu görülmektedir. Alan yazında var olan bu eksiği kapatmak, özel yetenekli bireyleri daha iyi tanımak, onların yaratıcılıklarını yaratıcı drama ile geliştirmek, sınav kaygıları ile başetmelerinde yol gösterici olmak, planlanacak diğer deneysel çalışmalara kaynak oluşturmak adına bu deneysel çalışma planlanmıştır.

$\mathrm{Bu}$ çalışmada özel/üstün yetenekli lise öğrencilerinin sınav kaygısı puanları üzerinde yaratıcı drama temelli sınav kaygısı ile başetme çalışmasının etkililiğinin incelenmesi amaçlanmiştır.

$\mathrm{Bu}$ deneysel çalışmanın hipotezleri şunlardır:

1-Deney ve kontrol gruplarına katılan katılımcıların son testleri incelendiğinde sınav kaygısı puanlarında deney grubu lehine anlamlı bir azalma olacaktır. 
2-Deney grubunun ön-son testleri incelendiğinde son test lehine sınav kaygısı puanlarında anlamlı bir azalma olacaktır.

\section{Yöntem}

Yaratıcı drama temelli sınav kaygısı ile başetme çalışmasının özel/üstün yetenekli öğrencilerin sınav kaygısına etkisini incelemeyi amaçlayan bu çalışmada ön-test, son-test, kontrol gruplu yarı deneysel desen kullanılmıştır.

\subsection{Katılımcılar}

Araştırmanın deney ve kontrol grubunu 2016-2017 eğitim öğretim y1lında Bilim ve Sanat Merkezine kayıtlı üstün tanısı almış 28 özel/üstün yetenekli lise öğrencisi oluşturmuş̧ur. Bu öğrencilerden 14'ü deney (5 erkek, 9 kız) grubunda 14'u kontrol grubunda (4 erkek, 10 kız) yer almaktadır. Çalışmada deney grubuna katılanlar gönüllülük esasına göre belirlendiğinden gruplara atama seçkisiz yapılamamış ve katılımcılar cinsiyet açısından eşitlenememiştir.

\subsection{Deneysel İşlem}

Deney grubuna uygulanan yaratıcı drama temelli sınav kaygısı ile başetme atölye çalışması her biri ortalama 60 dakika süren toplam 6 oturumdan oluşmaktadır. Deney grubuna katılan öğrencilere uygulama öncesi süreç hakkında bilgi verilmiş ve bilgilendirilmiş onam formu uygulanmıştır. Kontrol grubuna ise herhangi bir uygulama yapılmamıştır. Her iki gruba ön-test ve son-test olarak 20 maddeden ve dört alt boyuttan oluşan sınav kaygısı ölçeği uygulanmıştır. Deney grubu ile gerçekleştirilen yaratıcı drama temelli sınav kaygısı eğitimi ilk oturumunda ilk olarak grup kuralları belirlenmiş ve üyelerin kendilerine ilişkin davranışsal amaçlar belirlemeleri sağlanmıştır. Daha sonra üyelerle tanışma etkinliği yapılmıştır. Bu tanışma etkinliğinde öncelikle her bir üye kendi isminin önüne isminin baş harfi ile başlayan bir sıfat ekleyerek önce sıfatı sonra ismini söylemiş diğer üye de önce o üyenin sıfat ve ismini sonra kendi sıfatını ve ismini söylemiş ve son üyeye kadar süreç böyle devam etmiştir. Son üye kendisinden önceki 13 üyenin sifat ve ismini en son da kendi sıfat ve ismini söylediğinde etkinlik bitirilmiştir. Daha sonra her bir üyeye birer balon vererek üyelerin balonun bir tarafına kendi isimlerini yazmaları, diğer tarafina kendilerini temsil edebilecek istedikleri bir figürü çizmeleri istenmiştir. Sonra müzik eşliğinde balonları ile oynamaları müzik bittiğinde karşılarındaki üye ile göz göze gelerek ve balondaki figürü göstererek isimlerini bağırarak söylemeleri istenmiştir. Gruptaki her üye birbirleri ile karşılaşınca etkinlik sonlandırılmıştır. Son olarak her bir üyeye A4 kağıdı verilmiş A4 kağıdında 16 kare oluşana kadar ikiye katlamaları istenmiştir. Üyeler müzik eşliğinde her üyeye giderek her bir kutucuğa isimlerini ve onları temsil eden üç sıfatı yazmışlar daha sonra grup daire şeklinde oturarak ellerindeki kağıtları katlayarak kapatmışlardır. Daha sonra bir üye elindeki kağıdı açıp bakarak üç sıfat söylemiş ve hangi üye olduğu diğer üyeler tarafından tahmin edilmiştir. Her üye üç sıfat söyleyinceye ve bütün üyeler tahmin edilinceye kadar etkinliğe devam edilmiştir. İkinci oturumda grup üyelerine altı düşünce şapkası yaptırılmış ve her bir üyenin bu düşünce şapkalarını giyerek sınav ve sınav kaygısı ile ilgili yaratıcı düşünmeleri sağlanmıştır. Üçüncü oturumda grup ikiye ayrılmış altı düşünce şapkası renklerini temsil eden renklerde fon kartonuna o düşünce şapkasını ifade eden sınav ve sınav kaygısı ile ilgili cümleler ve sorular yazılmış ve her bir 
gruptaki üyelerin bu sorulara cevap vermesi istenmiştir. Daha sonra bu sorular ve cevaplarla ilgili bir hikaye yaratmaları istenerek bu hikayeleri canlandırmaları sağlanmıştır. Bu süreçte önemli olan sınav ve sınav kaygısı ile ilgili mantıklı ve gerçekçi düşünmelerini sağlamaktır. Dördüncü oturumda öğrencilere sınav ve kaygı hakkında bilgi verilmiş, sınav kaygısı ile başetme yöntemleri anlatılmıştır. $\mathrm{Bu}$ yöntemlerden hayalde rahatlama, kasıp gevşeme egzersizleri, mantıksız düşünceleri farketme ve yerine mantıklı düşünceler koyma etkinlikleri ayrıntılı olarak uygulamalı gösterilmiştir. Beşinci oturumda etkili ve verimli ders çalışma teknikleri anlatılarak grup ikiye ayrılmış her bir gruptan etkili ve verimli çalışma ile ilgili bir drama yapmaları istenmiştir. Altıncı oturumda üyelere oturum başladıktan itibaren bu oturuma kadar amaçları doğrultusunda değerlendirme yapmaları istenmiştir. Daha sonra üyelere kendileri ağacın bir parçası olacak şekilde bir grup ağacı yaptırılmış ve diğer üyelere ve lidere söylemek istedikleri alınmış ve oturum sonlandırılmıştır.

\subsection{Veri Toplama Araçları}

Sınav Kaygısı Ölçeği: Benson ve El-Zahhar (1994) tarafından geliştirilen ölçeğin, Akın ve Demirci (2012) tarafından Türkçeye uyarlama çalışmasında 335 lise öğrencisi üzerinde yapılan DFA sonuçları ölçeğin dört boyutta toplandığını ve iyi uyum verdiğini göstermiştir $\quad\left(x^{2}=332,20, \quad s d=160, \quad R M S E A=0,056, \quad C F I=0,92, \quad I F I=0,92, \quad G F I=0,91\right.$ ve $\mathrm{SRMR}=0,051)$ Ölçeğin iç tutarlılık güvenirlik katsayıları alt ölçekleri için sırasıyla (gerginlik, bedensel belirtiler, endişe, sinavlarla ilgisiz düşünceler) $.78, .77, .71, .80$ ve ölçeğin tamamı için .88 olarak hesaplanmıştır. Ölçeğin test-tekrar test güvenirlik katsayıları alt ölçekler için sırasıyla $.75, .64, .74$ ve .70 , ölçeğin tamamı için .65 olarak bulunmuştur. $\mathrm{Bu}$ çalışmanın verileri üzerinde ölçeğin Cronbach Alpha güvenirlik katsayısı sırasıyla; .80, .76, $.75, .82$ ve ölçeğin tamamı için .84 olarak hesaplanmıştır.

\subsection{Verilerin Analizi}

Süreç sonunda elde edilen verilerin analizinde gruptaki bireylerin sayısı dikkate alınarak non-parametrik testler kullanılmıştır. Deney ve kontrol gruplarına atanan katılımcıların ön testlerinde bir farklılık olup olmadığının belirlenebilmesi için MannWhitney U Testi yapılmış ve deney ve kontrol grubundaki katılımcıların ön testleri arasında bir farkl1lik bulunmamıştır (öntest toplam $U=55,00$, öntest gerginlik $U=60,50$, öntest bedensel belirtiler $U=38,50$, öntest endişe $U=68,00$, öntest sınavla ilgisiz düşünceler $\mathrm{U}=53,00, \mathrm{p}>0,05)$. Deney ve kontrol gruplarının son testleri arasinda farklilık olup olmadığını saptamak için Mann- Whitney U Testi uygulanmış ayrıca deney grubunun ön-son test karşılaştırması için ise Wilcoxon İşaretli Sıralar Testi kullanılmıştır. İstatistiksel işlem sonuçlarını yorumlayabilmek için anlamlılık düzeyi 0,05 olarak kabul edilmiştir.

\section{Bulgular}

\subsection{Birinci Hipoteze İlişkin Bulgular}

Yaratıcı drama temelli sınav kaygısı ile başetme çalışmasına katılan katılımcıların kontrol grubundaki katılımcılara göre sınav kaygısı puanlarında istatistiksel olarak anlamlı düzeyde fark olup olmadığını belirlemek için Mann Whitney $U$ testi uygulanmış sonuçlar Tablo 1'de verilmiştir. 
Tablo 1. Deney ve kontrol grupları sınav kaygısı sontest puanlarına ilişkin Mann Whitney U test sonuçları

\begin{tabular}{|c|c|c|c|c|c|c|}
\hline $\begin{array}{l}\text { Sinav } \\
\text { Kaygis1 }\end{array}$ & Son Test & $\mathbf{n}$ & Sira Ort. & Sira Toplam & $\mathbf{U}$ & $\mathbf{p}$ \\
\hline Toplam & Deney & 14 & 7,93 & 111,00 & $6,00 * *$ & 0,000 \\
\hline Puan & Kontrol & 14 & 18,90 & 189,00 & & \\
\hline Gerginlik & $\begin{array}{l}\text { Deney } \\
\text { Kontrol }\end{array}$ & $\begin{array}{l}14 \\
14\end{array}$ & $\begin{array}{l}9,79 \\
16,30\end{array}$ & $\begin{array}{l}137,00 \\
163,00\end{array}$ & $32,00^{*}$ & 0,025 \\
\hline Bedensel & Deney & 14 & 7,71 & 108,00 & $3,00 * *$ & 0,000 \\
\hline Belirtiler & Kontrol & 14 & 19,20 & 192,00 & & \\
\hline Endişe & $\begin{array}{l}\text { Deney } \\
\text { Kontrol }\end{array}$ & $\begin{array}{l}14 \\
14\end{array}$ & $\begin{array}{l}9,93 \\
16,10\end{array}$ & $\begin{array}{l}139,00 \\
161,00\end{array}$ & $34,00^{*}$ & 0,036 \\
\hline Sinavla & Deney & 14 & 9,43 & 132,00 & $27,00 *$ & 0,011 \\
\hline $\begin{array}{l}\text { İlgisiz } \\
\text { Düşünceler }\end{array}$ & Kontrol & 14 & 16,80 & 168,00 & & \\
\hline
\end{tabular}

Tablo 1 incelendiğinde yaratıcı drama temelli sınav kaygısı ile başetme çalışmasına katılan deney grubu ile bu uygulamaya katılmayan kontrol gruplarının sinav kaygisı son test puanlarının anlamlı derecede farklılaştı̆̆ görülmüştür (Toplam Puan $U=6,00, p<0,001$, Gerginlik $U=32,00, p<0,05$, Bedensel Belirtiler $U=3,00, p<0,001$, Endişe $U=34,00, p<0,05$, Sınavla İlgisiz Düşünceler $U=27,00, p<0,05)$. Bu farklılık incelendiğinde sinav kaygısı puanlarında gözlenen düşüşün deney grubu son test puanları lehine olduğu saptanmış ve birinci hipotez kabul edilmiştir.

\section{2. İkinci Hipoteze İlişkin Bulgular}

Yaratıcı drama temelli sınav kaygısı ile başetme çalışmasına katılan katılımcıların, sınav kaygısı ön ölçüm puanları ile son ölçüm puanları karşılaştırmasında deney grubu ön test ve son test puanlarına Wilcoxon işaretli sıralar testi uygulanmış ve sonuçlar Tablo 2'de gösterilmiştir.

Tablo 2 incelendiğinde yaratıcı drama temelli sınav kaygısı eğitimi atölyesine katılan deney grubu katılımcılarının ön test ile son test sınav kaygısı puanları karşılaştırıldığında, ön test ve son test puanları arasında anlamlı farklılıklar görülmüştür (Toplam Puan $z=-3,316$, $\mathrm{p}<0,01$; Gerginlik $\mathrm{z}=-2,499$; Bedensel Belirtiler $\mathrm{z}=-1,997$; Endişe $\mathrm{z}=-2,399$; Sınavla İlgisiz Düşünceler $\mathrm{z}=-2,223, \mathrm{p}<0,05)$. Bu farkl1lık incelendiğinde sinav kaygısı puanlarında gözlenen düşüşün son test puanları lehine olduğu saptanmıştır. Bu durum altı oturum süren deney grubuna uygulanan yaratıcı drama temelli sınav kaygısı ile başetme çalışmasının etkili olduğunu göstermiş ikinci hipotez kabul edilmiştir. 
Tablo 2. Deney grubu ön test ve son test puanlarına uygulanan Wilcoxon İşaretli Sıralar Testi sonuçları

\begin{tabular}{|c|c|c|c|c|c|c|}
\hline $\begin{array}{l}\text { Sinav } \\
\text { Kaygis1 }\end{array}$ & Ön-Son Test & $\mathbf{n}$ & Sira Ort. & Sira Toplam & $\mathbf{z}$ & $\mathbf{p}$ \\
\hline \multirow[t]{3}{*}{ Toplam Puan } & Negatif sıra & 0 & 0,00 & 0,00 & $-3,316 * *$ & 0,001 \\
\hline & Pozitif sıra & 14 & 7,50 & 105,00 & & \\
\hline & Eşit & 0 & & & & \\
\hline \multirow{3}{*}{ Gerginlik } & Negatif sıra & 1 & 5,00 & 5,00 & $-2,499 *$ & 0,012 \\
\hline & Pozitif sıra & 10 & 6,10 & 61,00 & & \\
\hline & Eşit & 3 & & & & \\
\hline Bedensel & Negatif sira & 1 & 6,00 & 6,00 & $-1,997 *$ & 0,046 \\
\hline \multirow[t]{2}{*}{ Belirtiler } & Pozitif sıra & 8 & 4,88 & 39,00 & & \\
\hline & Eşit & 5 & & & & \\
\hline \multirow[t]{3}{*}{ Endişe } & Negatif sıra & 1 & 2,50 & 2,50 & $-2,399 *$ & 0,016 \\
\hline & Pozitif sira & 8 & 5,31 & 42,50 & & \\
\hline & Eşit & 5 & & & & \\
\hline Sinavla & Negatif sıra & 2 & 3,00 & 6,00 & $-2,223^{*}$ & 0,026 \\
\hline İlgisiz & Pozitif sıra & 8 & 6,13 & 49,00 & & \\
\hline Düşünceler & Eşit & 4 & & & & \\
\hline
\end{tabular}

\section{Tartışma}

Özel/üstün yetenekli lise öğrencilerinin sınav kaygısı puanları üzerinde yaratıcı drama temelli sınav kaygısı ile başetme çalışmasının etkililiğinin incelendiği bu çalışmada, yaratıcı drama temelli sınav kaygısı ile başetme çalışmasına katılan deney grubu katılımcılarının ve bu uygulamaya katılmayan kontrol grubu katılımcıların son test puanları karşılaştırılmış ve sınav kaygısı son test puanlarında deney grubu lehine anlamlı farklılıklar bulunmuştur. Ayrıca deney grubu katılımcilarının ön test-son test sinav kaygısı puanlarında anlamlı bir farklılık bulunmuş ve sınav kaygısı son testlerinde azalma saptanmıştır. Elde edilen bu bulgular yaratıcı drama temelli sınav kaygısı ile başetme çalışmasının özel/üstün yetenekli lise öğrencilerinin sınav kaygısı puanlarını azaltmada etkili olduğunu göstermektedir. $\mathrm{Bu}$ durum katılımcıların sınav kaygısı ile başetmede yaratıcılıklarını kullanmalarından, aynı zamanda kendilerine verilen tartışma ve drama zamanlarını iyi değerlendirmelerinden, sınav kaygısı olduğunda ne yapmaları gerektiği ile ilgili başetme tekniklerini öğrenip oturum içerisinde uygulama şansı bulmalarından kaynaklanmış olabilir. Ayrıca bu çalışma öğrencilerin eğitimlerini sürdürdükleri yerde yani Bilim Sanat Merkezinde yapılmıştır. Çalışmanın öğrencilerin bildikleri bir yerde yapılması, özel/üstün yetenekli öğrencilerin yapılan etkinliklerde kendilerini ifade etme ve kendilerini yansitma konusunda rahat olmalarına ve yapılan çalışmada kendilerini rahat ve güvende hissetmelerine sebep olmuş ve yapılan çalışmanın etkili olmasına katkı sağlamış olabilir.

Özel/üstün yetenekli öğrencilerin sınav kaygılarını azaltmaya yönelik yapılan çalışmalar incelendiğinde Konyalıŏlu (2013) bilinçli hipnoz ve sınav kaygısı programının üstün yetenekli öğrencilerin sınav kaygılarını azaltmadaki etkilerini incelediği çalışmasında deneysel işlem sonucunda bilinçli hipnoz çalışmasına katılan katılımcıların sınav kaygısı kuruntu ve duyuşsallık alt boyutları puanlarında anlamlı derecede azalma saptarken, sınav kaygısı programı uyguladığı grubun duyuşsallık alt boyutu puanlarında anlamlı derecede 
azalma saptamış, kuruntu alt boyutu puanlarında ise istatistiksel açıdan anlamlı bir azalma saptamamıştır. $\mathrm{Bu}$ durumda hipnozun sınav kaygısını azaltmada etkili, sınav kaygısı programının ise kısmen etkili olduğunu belirtmiştir. Vogelaar, Bakker, Elliott ve Resing (2017) üstün yetenekli ve normal gelişim gösteren öğrencilerin sinav kaygisı üzerinde dinamik bir eğitim uygulamışlar ve bu eğitimin her iki grupta da sınav kaygısı puanlarını düşürmede etkili olduğunu saptamışlardır. Üstün yetenekli ve normal gelişim gösteren iki grup sınav kaygısı puanları açısından karşılaştırıldığında ise farklılık bulunmamıştır. Pols (2014), normal gelişim gösteren ve üstün yetenekli öğrenciler üzerinde uyguladığı deneysel programın sınav kaygısını düşürmede etkili olduğunu saptamıştır. Bu çalışmalarda yapılan deneysel çalışmaların etkili olduğu belirtildiğinden çalışmanın bu bulgusunu destekler niteliktedir. Alan yazında üstün yetenekli çocuğun sosyal ve duygusal özellikleri ve ihtiyaçlarından bahseden ayrıca normalden farklı olan istisnai hayal gücünün çocukta kaygı, endişe ve korkuların gelişmesine neden olabileceğine ilişkin çalışmalar mevcuttur. $\mathrm{Bu}$ çalışmalarda üstün yetenekli çocukların anlaşılmaya ihtiyacı olduğu, ailesinin doğru davranış sergilemesinin yararından, uygun eğitimler ve çalışmaların olması gerektiğinden bahsedilmektedir (Akarsu ve Mutlu, 2017; Gür, 2011; Mısırlı Taşdemir, 2003; Murdock Smith, 2013; Smutny, 2001). Misırlı Taşdemir (2003), Uyanık (2007) ve Gür (2011) üstün yetenekli öğrencilerin sınav kaygısı üzerinde mükemmeliyetçilik, yalnızlık ve kendine saygının da önemli rol oynadığını belirtmiş, yapılacak araştırmalarda bu değişkenlerin üzerinde çalışılması gerektiği ve üstün yetenekli çocuklarla iletişim kurarken aile ve uzmanlara önemli roller düştüğünü söylemişlerdir. Gür (2011) yaptı̆̆ çalışmada eğitim ortamlarında birçok üstün yetenekli çocuğun karşılaştığı sosyal-duygusal problemlerin, onların eğitim yaşantısından uzaklaşmak istemesine, ileride toplumsal sorunlar yaşamasına neden olabileceğini belirtmiştir. Sosyal duygusal problemlerin içerisinde yer alan kaygıyı arttırıcı en önemli faktör; çocuğun kendisini hiç kimsenin anlamadığı inancıdır. Bütün çocuklar gibi üstün yetenekli çocuklar da kendilerini rahatlatacak yetişkinlere ve baskı altında tutulmaya değil, mantıklı açıklamalara ihtiyaç duymaktadırlar. Çeşitli endişe ve kaygılar çocuğun cesaretini kaybederek gerçek yaşamdan uzaklaşmasına neden olabilir. Önünde bulunan büyük bir sınava hazırlanan bir çocuk ciddi anlamda sınav kaygısı yaşayabilir. Aşırı düzeydeki bu stres onu sınavlarından günler öncesinde bile hiçbir şey yapamaz, hayattan tat alamaz hale getirebilir. Çocuk kendisini kaygılandıran durum hakkında konuşmaya teşvik edilmeli, söyledikleri ve hissettikleri hakkında sorgulanmamalıdır. Bütün bunlar üstün yetenekli çocuğun sınav kaygısıyla başetmesi için oldukça etkili ve önemlidir. Bu yüzden psikoeğitim çalışmaları ya da diğer deneysel çalışmalar özel/üstün yetenekli öğrencilerin sınav kaygısı ile başetmesinde önemli bir rol oynamaktadır.

\section{Sonuç Ve Öneriler}

$\mathrm{Bu}$ çalı̧̧mada özel/üstün yetenekli lise öğrencileri ile yapılan yaratıcı drama temelli sınav kaygısı ile başetme çalışmasının öğrencilerin sınav kaygısı puanları üzerinde etkili olduğu ve deney grubundaki öğrencilerin kontrol grubundaki öğrencilere göre sınav kaygısı puanlarının anlamlı olarak azaldığı görülmüştür. Özel/üstün yetenekli lise öğrencilerinin sınav kaygısı puanları üzerinde yaratıcı drama temelli sınav kaygısı ile başetme çalışmasının etkili olduğu bu çalışmanın sonuçları doğrultusunda özel/üstün yetenekli öğrencilerin sınav kaygısı ve sınav kaygısı ile ilişkili olabilecek, mükemmeliyetçilik, benlik saygısı/kavramı, öz yeterlik, akademik öz yeterlik, kaygı gibi diğer değişkenler de ele alınarak farklı çalışmaların denenmesi için kurgulanmış deneysel çalışmaların yapılması faydalı olacaktır. Özel/üstün 
yetenekli öğrencilerin normal gelişim gösteren akranları ile karşılaştırıldığ 1 çalışmalara ihtiyaç vardır. Bu çalışmaların yapılması bu öğrencilerin gelişimsel özelliklerinin daha iyi anlaşılmasına sebep olabileceği gibi üstün yetenekli öğrenciler için çeşitli programların oluşturulmasına da kaynaklık edebilir.

Her çalışmada olduğu gibi bu çalışmanın da bir takım sınırlılıkları mevcuttur. Çalışmada deney grubuna katılan öğrencilerin Bilim ve Sanat Merkezindeki derslerine devamsızlıkları ve dönem sonu olması sebebiyle izleme ölçümü alınamamıştır. Çalışmada öğrencilerin deneysel çalışmaya katılmaya çok istekli olmamaları sebebiyle deney ve kontrol gruplarına katılan katılımcıların cinsiyeti eşitlenememiştir. Öğrenciler hem sınav hazırlığı yaptıkları hem de Bilim ve Sanat Merkezlerindeki bireysel derslerden devamsızlık yapmak istemedikleri için atölye çalışmasının süresi kısa tutulmuştur. Ayrıca deneysel işlem bittikten sonra kontrol grubuna da benzer eğitim verilmek istenmiş fakat kontrol grubundan uygulamaya katılmaya istekli yeterli katılımcı olmadığı için atölye çalışması yapılamamıştır.

\section{Kaynakça}

Akın, A. ve Demirci, İ. (2012). "Revize Edilmiş Sınav Kaygısı Ölçeği: Geçerlik ve Güvenirlik Çalışması”, Eğitim Bilimleri ve Uygulama, 11(21): 103-118.

Akarsu, Ö ve Mutlu, B. (2017). "Üstün Yetenekli Çocukları Anlamak: Çocukların Sosyal ve Duygusal Sorunları", Düzce Üniversitesi Sağlık Bilimleri Enstitüsü Dergisi, 7(2): 112116.

Alyaprak, İ. (2006). Üniversite Sınavına Hazırlanan Öğrencilerde Sınav Kaygısını Etkileyen Faktörlerin İncelenmesi, Yayınlanmamış Yüksek Lisans Tezi Ege Üniversitesi Sosyal Bilimler Enstitüsü, İzmir.

Başarır, D.(1990). Ortaokul Son Sınıf Öğrencilerinde Sınav Kaygısı, Durumluk Kaygı, Akademik Başarı ve Sınav Başarısı Arasındaki İlişkiler, Yayınlanmamış Yüksek Lisans Tezi, Hacettepe Üniversitesi, Sosyal Bilimler Enstitüsü, Ankara.

Barrows, J., Dunn, S. \& Lloyd, C.A. (2013). “Anxiety, Self-Efficacy, and College Exam

Grades", Universal Journal of Educational Research 1(3): 204-208.

Beer, J. (1991). "Depression, General Anxiety, Test Anxiety, and Rigidity of Gifted Junior High and High School Children", Psychological Reports, 69(3): 1128-1130.

Benson, J., \& El-Zahhar, N. (1994). "Further Refinement and Validation of the Revised Test Anxiety Scale", Structural Equation Modelling: A Multidisciplinary Journal, 1(3): 203-221.

Clark, B. (2002). "Growing Up Gifted Developing the Potential of Children at School and at Home", 6th ed. Upper Saddle River, NJ: Prentice Hall.

Çapulcuoğlu, U. ve Gündüz, B. (2013). "Öğrenci Tükenmişliğini Yordamada Stresle Başaçıkma, Sınav Kaygısı, Akademik Yetkinlik ve Anne-Baba Tutumları", Eğitim Bilimleri Araştırmaları Dergisi, 3(1): 201-218.

Demirci, İ. ve Erden, S. (2016). "Bilişsel Davranış̧̧ı Yaklaşıma Dayalı Grupla Psikolojik Danışma Uygulamasının 8. Sınıf Öğrencilerinin Sınav Kaygısına Etkisi”, Marmara Üniversitesi Atatürk Eğitim Fakültesi Eğitim Bilimleri Dergisi, 43: 67-83.

Dobson, C. (2012). Effects of Academic Anxiety on the Performance of Students with and

Without Learning Disablities and How Students Can Cope With Anxiety at School. Unpublished Master Thesis. Northern Michigan University.

Gençdoğan, B. (2006). "Lise Öğrencilerinin Sınav Kaygısı İle Boyun Eğicilik Düzeyleri ve

Sosyal Destek Algısı Arasındaki İlişkiler”, Atatürk Üniversitesi Sosyal Bilimler Enstitüsü Dergisi, 7(1): 153-164. 
Goetz, T., Preckel, F., Zeidner, M. \& Schleyer, E. (2008). "Big Fish in Big Ponds: A Multilevel Analysis of Test Anxiety and Achievement in Special Gifted Classes", Anxiety, Stress, and Coping, 21(2): 185-198.

Gür, Ç. (2011). "Üstün Yetenekli Çocukların Karşılaştı̆̆1 Sosyal ve Duygusal Problemler ve Bu Problemlerin Çözümüne ilişkin Öneriler: Arkadaş Edinme Sorunu, Alay Edilme, Anksiyete, Endişeler ve Aşırı Mükemmeliyetçilik üzerine bir çalışma”, ICONTE, Ankara: Sosyal Kitabevi, s. 1319-1326.

Hong, E. (1998). "Differential Stability of Individual Differences in State and Trait Test Anxiety", Learning and Individual Differences, 10(1): 51-69.

Kaçan Softa, H., Ulaş Karaahmetoğlu, G. ve Çabuk, F. (2015). "Lise Son Sınıf öğrencilerinin Sinav Kaygısı ve Etkileyen Faktörlerin İncelenmesi”, K. Ü. Kastamonu Eğitim Dergisi 23(4): 1481-1494.

Kanlı, E. (2011). "Üstün Zekalı ve Normal Ergenlerin Mükemmeliyetçilik, Depresyon ve Kayg1 Düzeyleri Arasındaki İlişkilerin İncelenmesi”, M.Ü. Atatürk Eğitim Fakültesi Eğitim Bilimleri Dergisi, 33: 103-121.

Kirişçi, N. (2013). Üstün ve Normal Zekâ Düzeyindeki Öğrencilerin Matematikte ÖzDüzenleyici Öğrenmeleri ve Motivasyonel İnançları. Yayımlanmamış Yüksek Lisans Tezi. İstanbul Üniversitesi, Sosyal Bilimler Enstitüsü, İstanbul.

Konyalıŏlu, A. P. (2013). Bilinçli Hipnoz İle Sınav Kaygısı Programının Üstün Zekâlı Öğrencilerin Sınav Kaygılarını Azaltmadaki Etkilerinin Karşılaştırılması. Yayımlanmamış Doktora Tezi. İstanbul Üniversitesi, Sosyal Bilimler Enstitüsü, İstanbul.

Liebert, R. M., \& Morris, L. W. (1967). "Cognitive and Emotional Components of Test Anxiety: A Distinction and Some Initial Data”, Psychological Reports, 20(3): 975-978.

Lufi, D., Okasha, S. \& Cohen, A. (2004). "Test Anxiety and Its Effect on the Personality of

Students With Learning Disabilities", Learning Disability Quarterly, 27: 176-184.

Manning, S. (2006). "Recognizing Gifted Students: A Practical Guide for Teachers", Kappa Delta Pi Record. Winter, 64-68.

MEB (2016). "Bilim ve Sanat Merkezleri Yönergesi”, Ankara: Milli Eğitim Bakanlığı.

Mısırlı Taşdemir, Ö. (2003). Üstün Yetenekli Çocuklarda, Mükemmeliyetçilik, Sınav Kaygısı, Benlik Saygısı, Kontrol Odağı, Öz Yeterlilik ve Problem Çözme Becerileri Arasındaki İlişkinin İncelenmesi. Yayınlanmamış Yüksek Lisans Tezi, Karadeniz Teknik Üniversitesi, Sosyal Bilimler Enstitüsü, Trabzon.

Moore, M. M. (2006). Variations in Test Anxiety and Locus of Control Orientation in Achieving and Underachieving Gifted and Nongifted Middle School Students. Unpublished Doctoral Dissertation, University of Connecticut, Connecticut.

Murdock Smith, J. (2013). "Understanding the Social and Emotional Needs of Gifted Children", Rivier Academic Journal, 9(2): 1-4.

Öner, N. (1990). "Sınav Kaygısı Envanteri El Kitabı”, Yüksek Öğrenimde Rehberliği Tanıtma ve Rehber Yetiştirme Vakfı Yayını No: 1. İstanbul.

Özbay, Y. (2002). "The Mediating Effects of Perfectionism and Coping on Test Anxiety of Gifted and Non Gifted High School Seniprs", 23th International Conferance of Stres and Anxiety, 12-14 Jully, Melbourne, Australia.

Özbay, Y. (2013). "Üstün Yetenekli Çocuklar ve Aileleri”, Ankara: TC Aile ve Sosyal Politikalar Bakanlığı Yayınları.

Pols, M. (2014). "Test Anxiety in Gifted and Average-Ability Children: Help!: An Experimental Study into Test Anxiety Among Gifted and Average-Ability Elementary School Children Using Dynamic Testing Methods", Faculty of Social \& Behavioral Sciences, Psychologie Bachelor Thesis, Leiden University. 
Rana, R.A. \& Mahmood, N. (2010). "The Relationship between Test Anxiety and Academic Achievement. Bulletin of Education and Research", 32(2): 63- 74.

Sarason, I. G. (1984). "Stress, Anxiety, and Cognitive Interference: Reactions to Tests", Journal of Personality and Social Psychology, 46(4): 929-938.

Smutny, J. F. (2001). "Stand Up for Your Gifted Child", Canada: Free Spirit Publishing.

Spielberger, C. D. (1972). "Current Trends in Theory and Research on Anxiety", In C. D. Spielberger (Ed.), Anxiety, current trends in theory and research. New York and London: Academic Press.

Uyanık, S. (2007). Üstün Yetenekli Çocuklarda Mükemmeliyetçilik, Yalnızlık ve Kendine Saygı Düzeyinin Sınav Kaygısı Üzerindeki Etkileri. Yayınlanmamış Yüksek Lisans Tezi, Uludağ Üniversitesi, Sosyal Bilimler Enstitüsü, Bursa.

Ünalan, P.C., Çifçili, S., Dinç, D., Akman, M. ve Topçuoğlu, V. (2017). "Üniversite Sınavına Girecek Olan Öğrencilerde Sınav Kaygısı Düzeyi, Sosyal Etkinlikler ve Rehberlik Hizmetlerini Kullanma Durumu", Nobel Med, 13(1): 61-69.

Westberg, K. L., \& Daoust, M.E. (2003). "The Results of the Replication of the Classroom

Practices Survey Replication in Two States", The National Research Center on the Gifted and Talented, Fall, 3-8.

Wholuba, B.H. (2014). Examination of the Motivation for Learning of Gifted and NonGifted Students as It Relates to Academic Performance. Doctoral Dissertation, Florida State University, Florida.

Vogelaar, B., Bakker, M., Elliott, J.G. \& Resing, W.C.M.(2017). "Dynamic Testing and Test Anxiety Amongst Gifted and Average-Ability Children", British Journal of Educational Psychology, 87(1): 75-89.

Yıldız, H.Y. (2007). Sınav Kaygısı Anne Baba Tutumları ve Mükemmeliyetçilik Arasındaki

İlişkinin İncelenmesi. Yayınlanmamış Yüksek Lisans Tezi, Gazi Üniversitesi Eğitim Bilimleri Enstitüsü, Ankara.

Zeidner, M. \& Schleyer, E.J. (1999a). "Test Anxiety in Intellectually Gifted School Students", Anxiety Stress and Coping 12(2): 163-189.

Zeidner, M.\& Schleyer, E.J. (1999b), "The Big-Fish-Little-Pond Effect for Academic Self-

Concept, Text Anxiety and School Grades in Gifted Children", Contemporary Educational Psychology, 24(4): 305-329. 